\title{
The Obstacles to Creative Democracy at Home and Abroad
}

Only sheer cynicism and defeatism will deny that it is possible to create a workable world government. There have been times when the moral ancestors of present day defeatists would have scornfully declared that a rule of law over a territory anything like as large as our present United States was impossible. They would have said that outside of family groups and small neighbourhoods, the custom of every man's hand against other men could not be uprooted... If peoples, especially their rulers, devoted anything like the energy physical, intellectual, and moral - that now goes into planning war, to planning for an enduring peace system, they could achieve world government. To surrender to defeatism is for intelligence to abdicate. It is to give up the struggle in a cause in which nothing less than the destiny of civilization is at stake. It is, however, as necessary to appreciate the immense difficulty of the undertaking as it is to have the will to take unreserved part in it. (LW15: 206)

In much the same vein as contemporary advocates of global democracy, Dewey firmly believed that the nature of globalization meant that global forms of democracy were necessary to manage the Great Society. However, Dewey ultimately problematized his own thought when examining the feasibility of global democracy. Writing just after the end of the Second World War, Dewey initially counters 'defeatism' over the ability to govern the globe by reminding his readers that it was once believed that the United States was too big a land mass over which to create rule of law and democracy. Going further, Dewey suggests 
that if as much thought was put into global democracy as it had been for planning war, it would be more than feasible to create a Great Community and govern the Great Society. However, this optimism towards the project of global democracy is tempered by Dewey's belief that there was an 'immense difficulty' in creating global democracy.

The 'immense difficulty' in the enacting of global democracy was the fact that the Great Society had ' ... invaded and partially disintegrated the small communities of former times without generating a Great Community' (LW2: 314). As a result, Dewey concludes that the '... new age has no symbols consonant with its activities' and provides no communication of signs and symbols between citizens who are involved in national and transnational associations and consequences engendered by the Great Society. Given the Great Society's technological advancement in communications (telephone, wireless telegraph), the irony of this state of affairs was not lost on Dewey:

The ties which hold men together in action are numerous, tough and subtle. But they are invisible and intangible. We have the physical tools of communication as never before. The thoughts and aspirations congruous with them are not communicated, and hence are not common.... Our Babel is not one of tongues but of the signs and symbols without which shared experience is impossible. (LW2: 323-4)

This is why, within The Public and Its Problems, Dewey pleaded for the 'divided and troubled publics' across not just America but the world to integrate in order to create a Great Community that could bring forth democratic governance at both the national and international level. And this plea is reiterated again in Dewey's work during the Great Depression and in the events that led to the Second World War. Why, then, did Dewey argue that the publics of the Great Society were divided and troubled publics? What was stopping the emergence of a Great Community?

Somewhat expediently, and all too typically in the abstract, Dewey ends the 1946 essay with the answers to such questions when he warns that whilst it was imperative to 'begin' the path towards global democracy it was important to recognize that: 
As has been only too proved by the two devastating world wars the movement toward production of more comprehensive social organisation, the very movement that brought national states into being has been widely arrested. (LW15: 209)

When taken with Dewey's conception of democracy in mind, it becomes clear that the forestalling of the emergence of a Great Community was not down to any spatial-temporal limits on the practice of democracy, but rather resulted from what Dewey saw as the arresting of creative democracy and the democratic community at the level of the nation state. The arresting of creative democracy and its ability to update the practices and institutions of democracy were forestalling the 'production of more comprehensive social organization' not only within the nation state but also outside the nation state. Of course, this answer itself begs the questions: What did Dewey take to be the reason for the arresting of creative democracy within the nation state? And how did this arresting of creative democracy within the nation state impact on the cause of global democracy?

\section{The eclipse of the public}

The answers Dewey provides to the questions above see him initially outdo democratic realism at its own game. In superficial agreement with democratic realism, Dewey argued that it was the complexity of the Great Society, which had led to the 'eclipse' of publics and a sense of community within nation states and the subsequent arresting of creative democracy. This had transpired because the Great Society's multiplication, intensification and trans-nationalization of associative behaviour now outstripped the comprehension and knowledge of average citizens (LW2: 314-17). The age when citizens could adopt a few general political principles, such as embracing states' rights vis-à-vis centralized federal government or free trade vis-à-vis protectionism, and apply them with confidence through supporting one political party over another was now essentially 
over. Citing the example of the problem of industrial tariffs, Dewey explained,

For the average voter today the tariff question is a complicated medley of indefinite detail, schedules of rates specific and ad valorem on countless things, many of which he does not recognize by name, and with respect to which he can form no judgment. Probably not one voter in a thousand even reads the scores of pages in which rates of toll are enumerated and he would not be much wiser if he did. The average man gives it up as a bad job. (LW2: 317)

Due to the fact that modern industry was 'too complex and intricate', citizens were essentially 'bewildered' by the machinations of the Great Society. Unable to correctly locate where the indirect consequences that were affecting their daily lives came from, citizens could now not generate publics who could foster the reform of the social institutions of the state to control and regulate such consequences:

An inchoate public is capable of organization only when indirect consequences are perceived, and when it is possible to project agencies which order their occurrence. At present, many consequences are felt rather than perceived; they are suffered, but they cannot be said to be known, for they are not, by those who experience them, referred to their origins. It goes, then, without saying that agencies are not established which canalize the streams of social action and thereby regulate them. Hence the publics are amorphous and unarticulated. (LW2: 317)

At first glance, one may find Dewey's account of what he took to be the eclipse of publics as not too dissimilar to the view of democratic realism. In fact, Dewey appears to hold the same conviction as Walter Lippmann when highlighting how the voting public struggled to cope intellectually with the complex manoeuvrings of the Great Society. However, whilst both Dewey and democratic realism locate the 'intelligence' of the masses as a key reason for the stuttering of democracy, they radically differ on what they believe were the reasons for such a state of affairs. Democratic realism took it to be the case that the masses were a priori 
incapable of ever grasping the contours of the Great Society because it was too complex and demanded expert rule. Dewey, on the other hand, saw the lost nature of the public and the collapse of democracy to be down to wholly contingent reasons that limited the intelligence of the masses.

Primarily, Dewey identified the limiting of the public's intelligence and subsequent eclipse as being a result of the fact that modern liberal democracy within the Great Society had only achieved 'bourgeois democracy' rather than actual creative democracy. The historic emergence of liberal democratic governments in the nineteenth century 'had been an accompaniment of the transfer of power from agrarian interests to industrial and commercial interests'. Whilst there had been a change in the social order, with the rise of democratic government and the handing of power to industrial and commercial interests, the ability to '.. command the conditions under which the mass of people have access to the means of production and to the products of their activity...' continued to give 'power to the few over the many'. The reality was that in liberal bourgeois democracies, power lay in the hands of 'finance capitalism', no matter the claims of so-called governments of, by and for all the people. And whilst Dewey freely admitted that it would be 'silly' to deny that there had been great gain for the masses within liberal democracies, such as qualified suffrage, freedom of speech, press and assembly, he also viewed it as intellectual hypocrisy to 'glorify these gains and give no attention to the brutalities and inequities, the regimentation and suppression' which plagued the system of economic liberalism (LW11: 296-7).

This was no understatement. Although US society in the 1920s was one of apparent prosperity, it was still marked by severe racist segregation, economic inequality, regressive income tax, precarious employment, lack of industrial democracy and a relatively non-existent welfare state. By the time of the Great Depression, when such material inequality and the lack of means to deal with such conditions became even more acute, Dewey lamented that there were now 'millions of people who have the minimum of control over the conditions of 
their own subsistence' (LW13: 300). ${ }^{1}$ Yet, as Dewey pointed out, 'no economic state of affairs is merely economic' (LW11: 295). The most unjust and immoral aspect of such an unequal economic state of affairs was the role they played in the eclipse of the public and the stunting of creative democracy:

The same forces which have brought about the forms of democratic government, general suffrage, executives and legislators chosen by majority vote, have also brought about conditions which halt the social and humane ideals that demand the utilization of government as the genuine instrumentality of an inclusive and fraternally associated public. (LW2: 303)

The halting of the social and humane ideals Dewey associated with creative democracy was inherently down to bourgeois democracy being founded on the idea that laissez-faire capitalism was the true expression of human liberty. This had arisen, Dewey stressed, because in the fight against arbitrary government action and for religious freedom, mid-nineteenth century philosophical branches of liberalism had identified the 'immutable truth' that human liberty was to be found in the practices of laissez-faire capitalism. In this sense, human nature and natural law could be said to be fulfilled when liberty was perceived as the equal right of every individual to conduct economic enterprise free from government constraint, so long as they broke no law on the statute books. This, in turn, was said to be socially beneficial because the activities of self-interested individuals would automatically create competition that would provide socially needed commodities and services. Any government intervention that interfered with this form of liberty was to be taken as an attack on liberty itself. This conception of liberty, which was presented by eighteenth and nineteenth-century liberals - from Adam Smith to Mill - as an 'immutable truth' across time and space, was ultimately used by the commercial and industrial classes to firstly usurp the vested interests of mercantilism and then serve as the hegemonic justification for bourgeois democracy (LW11: 26-7, cf. LW2: 291-3). ${ }^{2}$ 
Dewey found that the hegemonic perpetuation of the ideal that laissez-faire capitalism equalled the 'philosophy of liberty' had had a profound impact upon the intelligence of the masses and the subsequent eclipse of the public. By the 1930s, it was apparent that laissezfaire capitalism and its conception of liberty had delivered extreme stratification rather than the liberty of all. However, defenders of the status quo, such as commercial and industrial interests who benefited from these conditions and philosophies as social Darwinism, argued that the supposed natural inequalities of individuals in moral and intellectual make-up not only explained economic inequality but were the consequences of natural law. Against the failure of those who were naturally deficient in being innovative, independent and economically proactive stood the success of those 'rugged individuals' who managed to practise liberty and gain wealth and property (LW11: 286-7).

Defenders of the status quo again argued that any government intervention interfered with this form of liberty was therefore to be taken as an attack on liberty itself. Such arguments were indicative to Dewey of how, within the confines of bourgeois democracy, the very concept of intelligence itself had fallen under the strictures of laissezfaire capitalism. However, as he reminded his readers, this simply reflected the failure of modern proponents of liberalism and industrial and commercial interests to recognize, or admit, that individuals were formed by the interaction of the human organism with its environment, and how the current economic regime affected such interaction (LW11: 29-32, 47-8, 286).

In this sense, 'effective intelligence' was not an 'original, innate endowment'. No matter the differences in native intelligence between individuals, the reality was that the 'actuality of mind' was deposited by social habits and customs (LW2:366). Rallying against apologists of both laissez-faire capitalism and democratic realism, Dewey highlighted how economic relationships and hegemonic ideals of bourgeois democracy worked in tandem to limit the access of the masses to information and educative practices that could bolster their intelligence. The majority engaged in the production and distribution of economic commodities, 
argued Dewey, have ' ... no share - imaginative, intellectual, emotional in directing the activities in which they physically participate' (LW5: 104). The strictures of industrial and economic relations within the Great Society, such as the mass-production techniques of Fordism, meant that individuals tended to 'become cogs in the vast machine whose workings they do not understand, and in whose management they have no part or lot in' (LW11: 252).

However, Dewey's use of the term 'cogs' needs to be clarified because it does not simply translate into a belief that the masses had regressed and become less advanced humans in the Great Society. On the contrary, reflecting on the new habits of knowledge and industry in 1927, for example, Dewey highlighted how present-day citizens could, due to education and a relative popularizing of science, talk about and understand science in ways far more complex than their predecessors:

Capacities are limited by the objects and tools at hand. They are still more dependent upon the prevailing habits of attention and interest which are set by tradition and institutional customs. Meanings run in the channels formed by instrumentalities of which, in the end, language, the vehicle of thought as well of communication, is the most important. A mechanic can discourse ohms and amperes as Sir Isaac Newton could not in his day. Many a man who has tinkered with radios can judge of things which Faraday did not dream of. It is aside from the point to say that if Newton and Faraday were now here, the amateur and mechanic would be infants besides them. The retort only brings out the point: the difference made by different objects to think of and by different meanings in circulation. A more intelligent state of social affairs, one more informed with knowledge, more directed by intelligence, would not improve original endowments one whit, but it would raise the level upon which the intelligence of all operates. The height of this level is much more important for judgment of public concerns than are differences in intelligence quotients. (LW2: 366)

Contra democratic realism, Dewey held that citizens could, through improving education and media practices and forging a greater involvement in industry and politics, develop habits that would allow 
them to act more intelligently without necessarily making them 'omnicompetent' or improving their native levels of intelligence. The proof itself was already apparent in the skill and knowledge of the amateur and mechanic compared to that of Newton and Faraday. The struggle of masses to adequately judge public matters within the Great Society transpired because of a lack of habits rather than inability of the masses to ever master such habits.

Dewey argued that this lack of emphasis on developing the mind of the masses could also be found in the wider public education policies of liberal democracies, which failed to provide the masses with the knowledge they needed in order to make correct judgements about the nature of the Great Society they inhabited. The public school system merely reproduced the hegemony of laissez-faire capitalism and its conception of liberty. For example, between 1929 and 1935, 12 million Americans had reached the employment age and at least half had not found steady employment as a result of the Great Depression. What Dewey found equally appalling was how public education had ill-equipped young people to comprehend the Great Society and had perpetuated the so-called merits of laissezfaire capitalism:

It is terrible enough that so many youths should have no opportunity to obtain employment under the conditions set by the present economic system. It is equally terrible that so many young people should be refused opportunity in what we call a public educational system, to find out about the causes of the tragic situation, and, in large measure, should be indoctrinated in ideas to which the realities about them give the lie. Confusion and bewilderment are sufficiently rife so that it is not necessary to add to them a deliberately cultivated blindness. (LW11: 354)

Added to the intellectual hegemony of stratification, Dewey believed that technological innovation and subsequent integration into consumer capitalism also affected the ability of the public to comprehend their present circumstances. This largely concerned the nature of the new media technologies and their integration into mass production and 
mass consumption. Man after all, Dewey contended, was a 'consuming and sportive animal as well as a political one', and the power of 'bread and circuses' to distract citizens from political concerns was nothing new. But he took the sheer number and variety of modern cheap consumer products, such as the 'movie, radio, cheap reading matter and motor car', as a wholly unprecedented scenario of political distraction:

In most circles it is hard work to sustain conversation on a political theme; and once initiated, it is quickly dismissed with a yawn. Let there be introduced the topic of the mechanism and accomplishment of various makes of motor cars or the respective merits of actresses, and the dialogue goes on at a lively pace. The thing to be remembered is that this cheapened and multiplied access to amusement is the product of the machine age, intensified by the business tradition which causes provision of means for an enjoyable passing of time to be one of the most profitable of occupations. (LW2: 321-2)

Although Dewey did not hold that such modern media technologies and products had been purposefully created as a culture industry, the fact that they did not originate in deliberate desire to divert political interest did not lessen their effectiveness in that direction (LW2: 321). The use of modern technology and mass-production techniques to create mass consumer products thus lead to forms of mass consumption that often distracted citizens from political issues. ${ }^{3}$

When Dewey examined how new media technologies, such as the 'telegraph, telephone, radio, cheap and quick mails', impacted upon the dissemination of information as 'news' to the public, he saw even more cause for concern. News, as Dewey stated,

... signifies something which has just happened, and which is new just because it deviates from the old and regular. But its meaning depends upon relation to what it imports, to what its social consequences are. This import cannot be determined unless the new is placed in relation to the old, to what has happened and been integrated into the course of events. Without coordination and consecutiveness, events are not events, but mere occurrences, intrusions; an event implies that out of which a happening proceeds. (LW2: 347) 
The problem Dewey found with news coverage was that it centred on triviality and sensationalism. Driven by the 'catastrophic, namely crime, accident, family rows, personal clashes and conflicts', such news coverage did not supply continuity of coverage to its audiences but rather supplied whatever would be taken as the 'new par excellence. As a result, Dewey quipped that the contents of news coverage became so interchangeable that only the 'date of the newspaper' could inform us whether such events happened 'last year or this, so completely are they isolated from their connections' (LW2: 346-7).

The explanation of this state of affairs, argued Dewey, was also down to the mixing of business practices and interests with modern media technology. Bourgeois democracy's 'quasi-democratic' habits of free speech, free press and free assembly created fertile ground for different sources of news production and public discussion. However, such freedoms were structurally prone to being undermined by the fact that the centralization and concentration of the means of production and distribution also had concomitant effects upon the organization of the public press. As Dewey noted, the smoothest road to control of political matters was through the construction of public opinion, and it was no coincidence that the gathering and sale of news had become part of the existing system of 'pecuniary profit' (LW2: 348-9). This resulted in not only the influence of 'private interests in procuring suppression, secrecy and misrepresentation,' but also the importing of the hegemony of consumer capitalism into news production and dissemination. This was what Dewey took as the explanation for the sensationalist and triviality of what passed for news. Thus, either through the perpetuation of a certain style of consumer capitalism in news production and dissemination or through direct ownership and influence, Dewey believed that large corporate capitalism naturally influenced the publishing business (LW13: 168).

Contra the arguments of democratic realism and defenders of the laissez-faire capitalism, Dewey argued that the eclipse of the public was not down to its innate intellectual deficiency but largely down to the 
artificial intellectual inequality engendered by bourgeois democracy and elements of its consumer culture:

The indictments that are drawn against intelligence of individuals are in truth indictments of a social order that does not permit the average individual to have access to the rich store of the accumulated wealth of mankind in knowledge, ideas and purposes. There does not now exist the kind of social organization that even permits the average human being to share the potentially available social intelligence. Still less is there a social order that has for one of its chief purposes the establishment of conditions that will move the mass of individuals to appropriate and use what is at hand. Back of the appropriation by the few of the material resources of society lies the appropriation by the few in behalf of their own ends of the cultural, the spiritual, resources that are the product not of the individuals who have taken possession but of the cooperative work of humanity. (LW11: 38-9)

It was therefore useless, Dewey lamented, to ruminate about the apparent failure of democracy until the sources of its failure had been grasped and steps were taken, namely using government action to address such economic and intellectual inequality, to bring about that type of social organization that would deliver the masses with the correct knowledge to comprehend the Great Society and practise creative democracy. Quite simply, Dewey argued, without enacting such a change we 'have no way of telling how the apt for judgment of social policies the existing intelligence of the masses may be' (LW2: 366).

\section{The national and global eclipse of creative democracy}

The effects of the eclipse of the public meant that creative democracy at the level of the nation state had essentially been eclipsed. Not only did ordinary citizens have no real democratic control over the Great Society at the national level, but also publics were not able to emerge and articulate demands that could generate the reform of social institutions in the first place. Dewey realized that the eclipse of the public allowed 
the regime of 'bourgeois democracy' to continue to underpin the institutions and practices of political democracy at the nation state level. Due to the fact that democratic government had arisen along side laissez-faire ideas of liberty, capitalism and the practice of democracy were now seen as 'Siamese' twins, where to attack one was to threaten the life of the other (LW13: 137). Indeed, Dewey took the example of the application of laissez-faire to individual intelligence to be indicative of how liberalism's tenets had become part of a wider political malaise within political democracy, which now acted as 'an instrument of vested interests' (LW11: 35).

This in turn had a pincer effect on the nature of political democracy under bourgeois democracy and its perpetuation of the eclipse of the public. On one hand, Dewey argued that in the 1920s and 1930s political parties ruled but they did not govern, acting as quasi 'servants of the same dominant railway, banking, and corporate industrial forces' (LW6: 186, cf. LW5: 442). This was not just through blatant corrupt control of government, but rather because the hegemonic identification of capitalism and democracy and the ability of business to actually organize itself as a public meant that it was able to reform the state and government in much the same way as 'dynastic interests' controlled government two centuries earlier (LW2: 302). In the inevitable clash between private property interests and the interests of the masses, all the 'habits of thought and action' impelled the institutions of political democracy to side with the former over the latter (LW6: 159).

On the other hand, the fact that political parties acted in the interests of capital rather than people had significant impact on the actual eclipse of the public. Government intervention on the effects of such an economically and intellectually stratified society was always palliative and dealt with symptoms rather than what Dewey took as the causes of such a state of affairs. This, in turn, locked the masses into the perpetual supporting of one impotent political party over the other, breeding a swing-style democracy where the 'tidal wave' swamps one party and the 'landslide' carries the other into office. In such a form of politics, instead of real policy difference, it was rather 'habit, party funds, the skill of 
managers of the machine, the portrait of the candidate with his firm jaw, his lovely wife and children, and a multitude of other irrelevancies' determined the outcome of political democracy (LW2: 311).

The impotency of existing political forms to direct and manage the social effects of the Great Society was also now generating 'distrust in political democracy and all forms of popular government' (LW13: 105-6). This was because political democracy, with its established institutions and practices under the hegemonic control of laissez-faire capitalism, had seen its 'symbols lose connection with the realities behind them' (LW11: 51). The majority of the voting public convinced that there was 'no important difference between the two old parties' and that to vote for one over the other was to signify very 'little' had lost faith with democracy (LW6: 185). Not only did this further add to the political apathy engendered in the majority under the auspices of bourgeois democracy and its consumer culture, but with such public apathy, political democracy itself became stratified and turned into just another 'business' run by the 'bosses' and 'managers' of the 'political machine'. Political democracy was thus now left to the machinations of professional politicians and elites, who rather than attempting to serve the public looked to keep or obtain power for the sake of keeping or obtaining power within the confines of bourgeois democracy (LW2: 321, LW7: 353-4).

The ultimate political effect of the eclipse of the public within the nation state was destruction of the Deweyan sense of democratic community and disharmony within the nation state. This point is pivotal; whilst Dewey believed citizens were unable to correctly locate where the indirect consequences that were affecting their daily lives came from, and hence could not generate publics which could foster the reform of social institutions of the state to control and regulate the consequences of the Great Society, he did not believe that citizens could no longer generate publics. As he pointed out,

It is not that there is no public, no large body of persons having a common interest in the consequences of social transactions. There is too much public, a public too diffused and scattered and too 
intricate in composition. And there are too many publics, for conjoint actions which have indirect, serious, and enduring consequences are multitudinous beyond comparison, and each one of them crosses the others and generates its own group of persons especially affected with little to hold these different publics together in an integrated whole. (LW2: 320)

The irony of the Great Society was that the more it made citizens more interdependent through its division of labour and production, the more it seemed to create divisions of interest between various groups across society. In fact, due to the inequality and stratification of bourgeois democracy, Dewey saw that groups and their publics referred back to an approach of being antagonistic and hostile towards one another, rather than democratically addressing the cause of their dissatisfactions. The emergence 'in political life of populist movements, square deals, new deals, accompanies depressions on the part of those most directly affected - farmers, factory labourers -' was indicative of how such groups were kept from 'uniting politically by divergence of immediate interests' (LW13: 106). Under bourgeois democracy, then, the educative rhythm of creative democracy, which looks to ensure a perpetual equality of communication and co-operative problem-solving as social conditions and conceptions of moral value shift throughout history, was non-existent.

Stuck with old and outdated social institutions, a form of democracy that was actually not democratic, and an eclipse of the public and community which could bring reform to such social institutions, creative democracy was thus stunted at the nation state level. Political democracy in America was a prime example of this process, where the state had not reformed its social institutions, such as wider and reformed education, workplace democracy and comprehensive unemployment insurance, and was now unable to deal with the consequences of the Great Society. Indeed, the American institutions and practices of political democracy themselves had not been updated and struggled to cope with the new demands placed upon them. As Dewey noted, whilst Americans had inherited the local town hall meetings of their agrarian 
forefathers, these practices were now insufficient to enact reforms suitable for 'national affairs - now also affected by world conditions' (LW13: 95, cf. LW2: 306).

Even at the federal level, the success of industrial forces in controlling political parties had locked in what Dewey viewed as a flawed system of two-party adversarial politics. The idea that the conflict between political parties would bring out 'public truths', stressed Dewey, was a kind of 'political watered down version of the Hegelian dialectic, with its synthesis arrived at by a union of antithetical conceptions' (LW11: 51). And whether it was the 'rugged individualism' of the Hoover regime or the 'piecemeal policies undertaken ad hoc' of Roosevelt's New Deal, which whilst seeming radical did not really reform the 'institutional scheme of things', political democracy merely 'drifted' along, largely consolidating the economic and intellectual stratification of bourgeois democracy (LW11: 45, 61-2, cf. LW13: 315). The result, as Dewey observed, was that the Great Society and its new age of human relationships had 'no political agencies worthy of it' (LW2: 303).

It has become the norm to read Dewey's account of the eclipse of the public and the stunting of creative democracy as simply being concerned with the American nation state. However, there is no doubt that Dewey's claim that the Great Society had no political agencies worthy of it extended to matters of global democracy. As outlined above, one of the underlying themes of The Public and Its Problems and his writings thereafter is of the need for the Great Society to become a Great Community. And Dewey knew that the Great Society did not just stretch across North America but rather traversed the world's continents. That such an international Great Community and global democracy was not forthcoming due to the eclipse of the public was also paramount in Dewey's mind. Writing in 1939, Dewey reflected on how, since the First World War, the 'world communities' had failed to 'meet and forestall' needed change and left 'us with old problems unsolved and new ones added' (LW13: 316).

Dewey held that the failure to initiate such change was undoubtedly down to the fact that bourgeois democracy and the breakdown 
of creative democracy within the nation state made such change improbable. This was down to two interrelated reasons. The first reason was that the hegemony of bourgeois democracy always meant that political leaders would attempt palliative measures that maintained the hegemony of capitalism and its conception of liberty. We have seen how this strangled the reform that Dewey thought was needed at the level of the nation state. However, bourgeois democracy's control of the Great Society was not only based on domestically stratified societies in the West, but functioned through a global economy based on asymmetric relations between the global North and South. As a basic provision of global democracy, the wretched of the earth would have been set free from the shackles of imperialism and the whole of the global economy would have restructured (MW11: 139-42). This, however, was unforthcoming as leaders replicated their palliative measures that maintained the hegemony of capitalism and its conception of liberty in the global economy.

The second reason was that the eclipse of the public meant citizens were in no position to demand their leaders enact such changes. In fact, the consequences of the Great Society and the eclipse of the public and community at the nation state undoubtedly had detrimental effects on how nation states viewed and conducted international relations towards one another. As Dewey noted in The Public and Its Problems, throughout history man has had problems getting on with his fellows, even in his neighbourhood. With the Great Society's engendering of the transnational forms of relationships and interdependence, Dewey noted that man was not now 'more successful' in getting on with his fellows 'when they act at a great distance in ways invisible to him' (LW2: 317). The subsequent problem of there being too many publics who were 'diffused and scattered and too intricate in composition', who were subsequently antagonistic towards one another, was therefore not confined to groups within the nation states, but also extended to publics between nation states.

As the 1930s had shown, antagonism towards citizens of other nation states, either through outright fascism or ideals of isolationism, could 
be seen to be one of the last points of unity that the divided and troubled publics of nation states had left. It was therefore no surprise to Dewey that the failure of world communities to meet and forestall the failings of bourgeois democracy and regulate the transnational consequences generated by the Great Society through creative democracy at home and abroad had seen the growth of 'exacerbated Nationalism' and left democracy both as an ideal and as a form of government under attack from both the 'right and left' (LW13: 106, 316). As Dewey noted,

The career of individuals, their lives and security as well as prosperity is now affected by events on the other side of the world. The forces back of these events he cannot touch or influence - save perhaps by joining in a war of nations against nations. For we seem to live in a world in which nations try to deal with the problems created by the new situation by drawing more and more into themselves, by more and more extreme assertions of independent nationalist sovereignty, while everything they do in the direction of autarky leads to ever closer mixture with other nations - but in war. (LW13: 180)

The rise of fascism and hyper-nationalism was the exemplar of this process and was essentially explained by the inequality and stratification of bourgeois democracy and its inability to provide citizens with the intellectual and political means of perceiving and controlling the consequences generated by the Great Society. Dewey saw the success of fascist movements as being down to their ability to fill the political void citizens experienced in bourgeois democracy by momentarily appearing to offer an explanation and political solution to the drastic changes engendered by living in such an interdependent world. Of course, such explanations and political solutions were a mirage that led to totalitarianism. Rather than creating a community in Dewey's sense, such movements attempted to restore a simulacrum of a community, such as völksgemeinschaft, that were hostile not only to bourgeois democracy but also to the ideals of creative democracy and the Great Community (LW13: 176, 315-16). ${ }^{5}$

This was the scenario Dewey feared most when considering the future of global democracy: the eclipse of the public in nation states 
and the consequences engendered by the Great Society leading citizens to turn away from forming a Great Community and turning upon one another. This view is summed up when, in the midst of the Great Depression, trade protectionism and the increasing threat of another world war, Dewey castigates the hostility of not only fascism, but also the eclipsed publics contained within bourgeois democracies towards the ideals of global democracy and a Great Community:

We cannot blame our Government or any other government for not instituting new policies as long as the peoples themselves are engaged in the futile task of identifying patriotism with isolation, and trying to obtain independence without regard to the interdependence that now exists. It is for us, the people, first to develop a genuine cooperative spirit and sense of mutual interests that bind the nations of the world together for weal or woe - and at the present time so largely for woe. The principle of good neighborliness is as fundamental in international matters as in the village and city ... We shall refuse to live up to it at our peril, the peril of depression, unemployment, degraded standard of living, and of war that will kill millions more and destroy billions more of property. (LW11: 263-4)

Dewey believed that this call for a new generation to inherit democracy as a way of life and reinvent democracy globally was a responsibility that the world could not afford to turn its backs on. However, Dewey's underlying point was that this inheritance could not be claimed under the auspices of bourgeois democracy. It was thus bourgeois democracy and the Great Society's engendering of 'divided and troubled publics' within and between nation states and the breakdown of creative democracy at the nation state level that Dewey saw as the immense difficulty' facing global democracy. Without informed and educated publics who could comprehend the complexity and trans-national nature of the Great Society, communicate transitionally and challenge the hegemony of bourgeois democracy, there was simply no chance of real democratic innovation at home or abroad. Put simply, until the Great Society was converted into a Great Community, the public would perpetually remain eclipsed (LW2: 324). 
John Narayan - 9781526101020

Downloaded from manchesterhive.com at $04 / 26 / 2023$ 02:18:46AM 